\title{
Integrated sustainability analysis on green building development in China: case study of three green practices
}

\author{
Z. C. Cai ${ }^{1,2}$ \& R. Wennerstern ${ }^{2}$ \\ ${ }^{I}$ School of Architecture, Southeast University, China \\ ${ }^{2}$ Department of Industrial Ecology, Royal Institute of Technology (KTH), \\ Sweden
}

\begin{abstract}
China has adopted Sustainable Development as an inequitable strategy for the whole country in all industries. In the civil construction sector, sustainability in China is regarded as the development of Green Building.

Due to the promotion by Chinese government, more and more buildings are emerging in China under the name of "Green". This paper offers a general overview of the current green trend in China and presents a specific analysis on three cases to search for the proper approach for China's unique situation.

The green practices are categorizes into three types: Modern Vernacular Architecture, Eco-offices and Mass-housing, according to their features in scale, location and function. Three specific cases were selected and the analysis of the different types was made. The analysis of the three projects is made from the perspectives of technology, economy, environmental impact, and social aspects, respectively.
\end{abstract}

Finally, the paper argues that an adaptive and holistic approach should be found for the development of Green Building in China.

Keywords: China, Green Building, new cave house, eco-office, Mass-housing.

\section{Introduction}

\subsection{General background}

Most of the current studies on Green Building are based on situations in the developed world. However, the urgent demand of application emerges in developing countries which are very different from developed countries in terms 
of economic feasibility, population, land conditions, policy and so on. Furthermore, major urbanization will happen and is happening in developing countries.

For instance, the past thirty (1978-2008) years witnessed fast and large-scale urbanization in China, both as a force and as a result of the rapid economic growth, which started from 1978 due to the Economic Reform. It was projected that from 2003 to 2020 there would be 420 million people moving into cities [1], in search of a better life. This mass migration, as a result of urbanization, has been accompanied by more and more critical challenges, such as energy scarcity, air pollution, land abuse, environmental degradation and urban population explosion, etc. The urbanization rate in 2006 was $43.9 \%$ [2].

As one of the fundamental facts, China is a big developing country, both in population (1.3 billion) and in territory size ( 9.6 million $\mathrm{km}^{2}$, excluding oceanic territory). Although China is abundant in many types of resources in terms of total reserve, it is very poor in terms of per capita reserve because of the huge population. China is especially scarce in arable land and water. The arable land per capita of China was $934 \mathrm{~m}^{2}$ in 2005 , which is $40 \%$ of the world average level [3], and the water resources per capita were $2125 \mathrm{~m}^{3}$ in 2005 [4] and $1927 \mathrm{~m}^{3}$ in 2006 [2], which is around one fourth of the world average $\left(8210 \mathrm{~m}^{3}\right.$ in 2005 [4]).

Furthermore, China's energy supply relies too much on coal, which accounted for $69.4 \%$ of primary energy consumption in 2006 [2]. This heavy reliance on coal has caused severe air pollution and acid rains in China, as well as producing the main GHG emissions.

Another valuable fact about China is its long history and a number of varieties in different cultures. Along with its diverse geographic and climatic types, China has high richness in vernacular architecture. These traditional buildings are mainly located in rural areas and still house a large amount of the rural population. They are also of great importance due to the traditional wisdom embedded in their design and construction being adaptive to local contexts. Below are some examples of this.

Courtyard House, which represents the northern residential typology, arranges rooms around an internal courtyard to enhance natural ventilation and accept more sunshine, as well as family life being organized by the yard;

Elevated House, which represents the south-western residential typology, puts main rooms on the second floor and leaves the ground floor open to cope with the high humidity and hot climate;

Cave House, which represents the north-western residential typology, was built from the caves in the earth and has a cool indoor temperature in the hot summer and a warm temperature in the cold winter because of the thick earth acting as a good insulator;

Water-town, which represents the south-eastern typology of small towns, was built along rivers. The rivers function as the main communication networks and also cool the houses in the hot summer. 
Tu Lou or Earth Tower, which represents an exclusive Ke Jia (migrant) ethnic residential typology, was built to defend against local people's attacks. The ethnic inhabitants migrated from the north to the south to flee the wars, but had to face the hostile natives in the beginning; and so on.

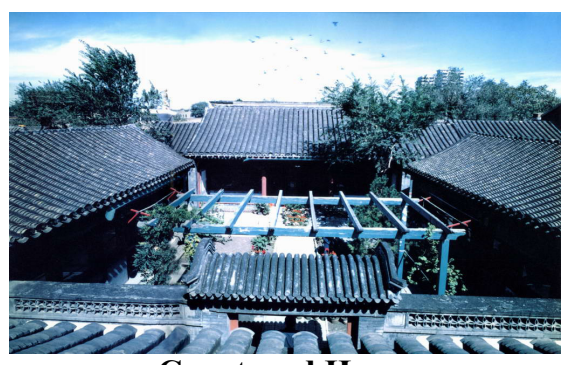

Courtyard House

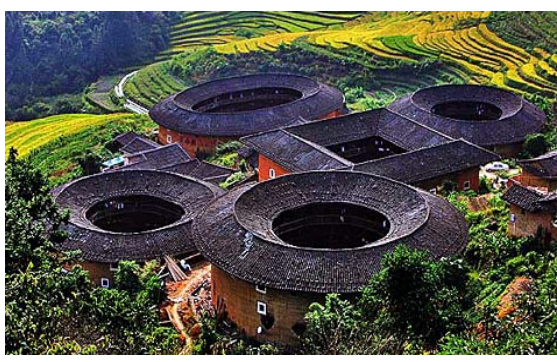

Tu lou, Earth Tower

Figure 1: Different vernacular buildings.

Last but not the least, from the economic point of view, although China has a huge total GDP (1889930 million dollars in 2005), China is still a developing country with very low GDP per capita (1449 dollars in 2005, while the world average was 5647 dollars in 2005 [4]). The average living standard in China is still low compared with that in west Europe or North America.

\subsection{The situation of Green Building in China}

In 2006, China had a total building floor area of 40 billion $\mathrm{m} 2$, and it was projected that an additional 28billion $\mathrm{m}^{2}$ floor area will be built before 2020 [6]. However, $95 \%$ of the 40 billion $\mathrm{m} 2$ existing buildings and $80 \%$ of the 2 billion $\mathrm{m} 2$ new buildings per year are energy intensive [6], because of:

- $\quad$ poor exterior wall insulation;

- weak windows: low air-tightness, low-quality glazing;

- improper design: not climate relevant, relying too much on ACMV;

- low-efficiency management.

As one of the consequences, the proportion of energy consumed by buildings in the total energy consumption in China rose from $10 \%$ in the 1970 s to $27.45 \%$ in 2001 [7], and is still rising rapidly due to the fast growing urbanization and improved interior comfort of new and retrofitted buildings, as well as the bad. China, with the biggest population and almost the lowest resources per capita in the world, has set up sustainability as its main development strategy. In the civil construction sector, sustainability is regarded as Green Building. Green Building is specifically defined, according to Chinese contexts, as buildings that are "energy efficient, land efficient, water efficient, material efficient" and "environmental friendly", emitting less pollution during the whole life cycle, and meet specified indoor environmental standards at the same time [8]. One of the main objectives of Green Building is to save energy, as much as $50 \%$ compared 
to those buildings constructed under 1980s building code without any specific energy-efficient measurements [8].

A series of policies and laws have been enforced since the early 1990s, in order to promote the development of Green Building:

- Energy Conservation Design Standard for New Heating-supplied Residential Buildings, JGJ 26-95, 1996

- Energy Conservation Law, 1998

- Technical Code for Renovation of Existing Heating-supplied Residential Buildings, JGJ 129-2000, 2001

- Design Standard for Energy Efficiency of Residential Buildings in Hot Summer and Warm Winter Zone, JGJ 124-2001, 2001

- Design Standard for Energy Efficiency of Residential Buildings in Hot Summer and Cold Winter Zone, JGJ 75-2003, 2003

- Design Standard for Energy-efficient Public Buildings, GB 50189-2005, 2005

- Evaluation Standard for Green Building, GBT50378-2006, 2006

- Renewable Energy Law, 2006

- Urban and Rural Planning Law, 2007

- Energy saving Law, 2007

- "100 demonstrating green buildings" program, funded by Ministry of Construction, and so on.

This promotion has played such a great role that thousands of square meters of buildings have been constructed since 2000, and more are being under constructed, under the name of "Green Building". These green buildings can mainly be categorized as three types, which are Modern Vernacular Architecture, Eco-offices, and Mass Housing Projects. This paper presents an integrated sustainability analysis on three specific cases from the technical, economic and social perspective, to search for a proper approach for China's unique situation.

\section{Case study}

\subsection{Modern Vernacular Architecture: Dongxin New Cave Housing Project}

\subsubsection{Introduction}

The Cave House is a typical housing typology in the upper and middle basin of Yellow River, where the Yellow-Earth Plateau is located. The climate there is arid, hot in summer and cold in winter. The thick level of yellow earth is dry and load-bearable, thus it is easy to dig out caves from the earth. Cave House has been a main rural residential type in this area for thousands of years and is still housing a large number of rural inhabitants.

There are three types of Cave Houses depending on how the caves are made: cliff-side caves, sunken-yard caves, and independent caves. The Cave House has both advantages and disadvantages. 


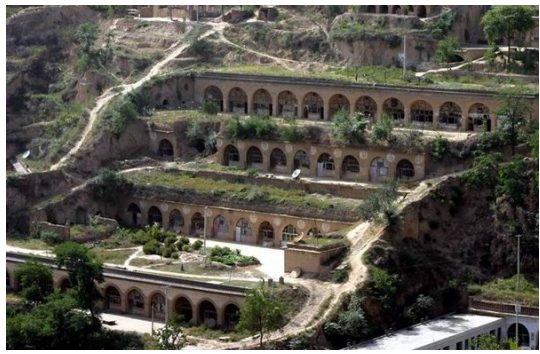

Old Cave House 1

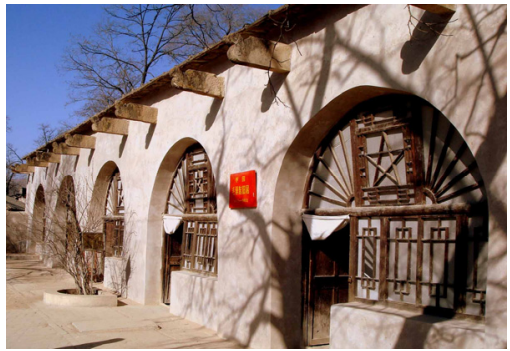

Old Cave House 2
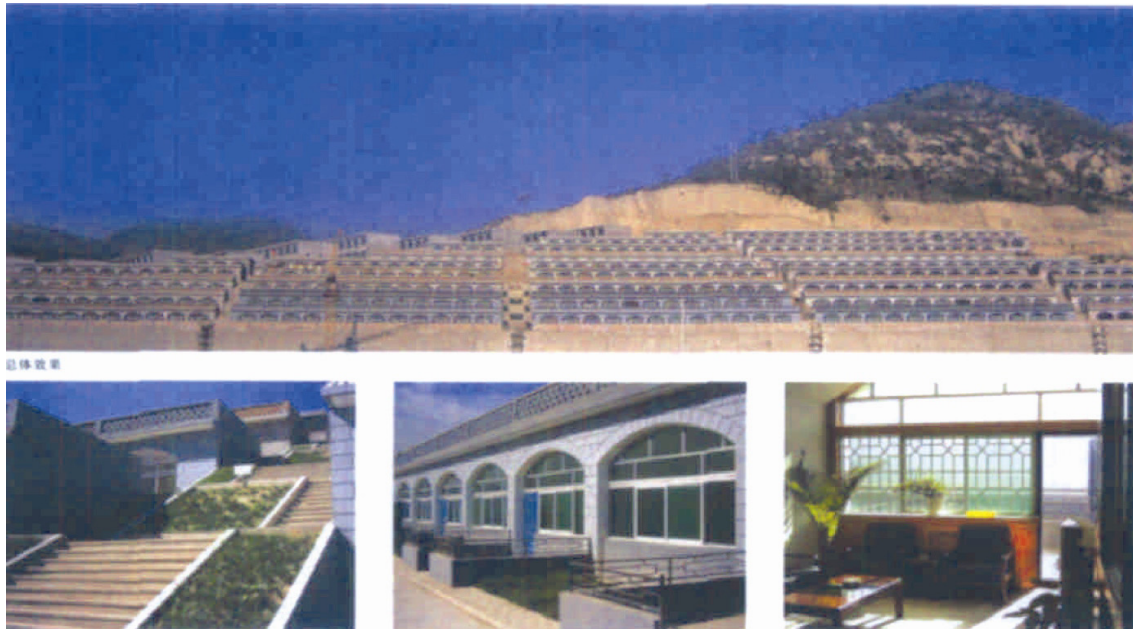

Dongxin New Cave Housing

Figure 2: $\quad$ Old and new cave house.

Advantages:

- low-price and easy construction;

- local materials;

- thick earth as a very good insulator, which makes the cave cool in summer, warm in winter;

- utilization of steep slopes, which are not suitable for normal construction and farming.

Disadvantages:

- $\quad$ poor natural lighting inside;

- poor ventilation;

- no indoor sanitation facilities.

Based on the above analysis, a concept of the New Cave House is formed by some researchers and also some New Cave Houses were built, one of which is the Dongxin Project. 
The Dongxin Project is a large-scale cave housing project, with a site area of $28000 \mathrm{~m}^{2}$ and a total floor area of $31500 \mathrm{~m}^{2}$. The project was finished in 2004 and housed 322 households. It provides better infrastructure on a neighborhood level, such as roads, sewerage system, and modern facilities inside the cave, such as electricity, heating, gas, water and indoor toilets. Some design innovations also help to improve the indoor climate very much, for example, a small sunken back yard for ventilation and natural lighting, a solar heater providing hot water and natural cooling through an underground air duct. The cave's structure was designed and built in a modern engineering way to adapt to the requirement for durability [9].

\subsubsection{Discussions}

In general, the Dongxin Project is a good example of rethinking traditional architecture and it attempts to adapt the old housing idea to modern life, without the consumption of too much additional energy and resources. The project has shown the capability of vernacular buildings' survival in the modern and westernized era. Furthermore, the affordable technology, indigenous technique, and native Chinese wisdom were revealed in the project. The architect's efforts and respect for the traditional culture could be generalized to other projects.

However, the project is rather geographically specific and is not responsive to the main challenges of rapid and large-scale urbanization in China. To some extent, the project is not efficient in land-use, since all of the houses are onestory due to the nature of the "cave".

To sum up, the Dongxin Project could be regarded as "green" not only in environmental protection, but also in cultural conservation, although it did not provide answers for the critical challenges in cities.

\subsection{Eco-office: office of the Shanghai Institute of Building Science (SIBS), Shanghai}

\subsubsection{Introduction}

The SIBS Eco-office is a demonstrating project funded by the Shanghai Government. It won the first prize in the "Green Building Innovation Competition, 2005", which was organized by the Ministry of Construction. The project, located in the suburban area of Shanghai, has a floor area of $2000 \mathrm{~m} 2$ and functions as a branch office for the Shanghai Institute of Building Science. It was built in 2004 .

The Eco-office implemented a number of technical equipment and methods to build a green building, such as:

- good insulation and windows: exterior wall, $\mathrm{K}=0.27-0.33 \mathrm{~W} /\left(\mathrm{m}^{2} \mathrm{~K}\right)$, windows, $\mathrm{K}=1.65-1.83 \mathrm{~W} /\left(\mathrm{m}^{2} \mathrm{~K}\right)$;

- mechanically adjusted exterior shadings;

- enhanced natural ventilation by solar heater during temperate seasons;

- renewable energy: solar heater and solar cell;

- high-efficiency air-conditioning equipments;

- $\quad$ water recycling and local micro grey water treatment;

- roof garden and interior planting. 

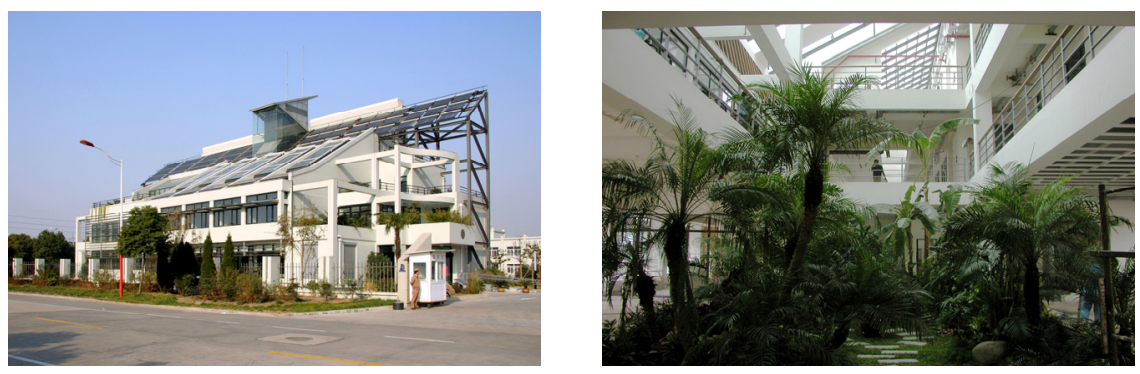

Figure 3: $\quad$ Photos of the SIBS Eco-office.

According to the SIBS' report [10], the building's annual energy for heating and cooling is $30 \mathrm{kwh} / \mathrm{m}^{2}$ (reference building: $100 \mathrm{kwh} / \mathrm{m}^{2} . \mathrm{a}$ ), and the local grey water plant generates 20 tons grey water per day from recycled domestic wastewater and rains. The Eco-office's construction cost RMB 4600yuan $/ \mathrm{m}^{2}$ (reference building: $3100 y u a n / \mathrm{m}^{2}$ ). The cost has increased by $48 \%$ and the payback time is about 22.3 years. The high cost is partly because of the small scale of the building as a demonstration project.

\subsubsection{Discussions}

The SIBS office is a government-funded project. Its initial idea is to demonstrate the green technology, thus the design idea is rather technology-dependent. Since its financial support was other than market-oriented, it was not very cost-benefit effective, thus it is hard to generalize. Since 2005, there has been a new requirement for green buildings by the Ministry of Construction that the additional cost should not exceed $20 \%$ of the reference building.

The project is located in a suburban area; however, the SIBS' headquarters is located in the city center. Most of the staff working in the Eco-office live in the city and have to commute to the Eco-office every day. From this point of view, the building is not ecological on an urban level.

To sum up, the SIBS Eco-office represents the official idea of Green Building and functions as a demonstration project and it has done a good job in terms of this. The "green" idea is somewhat regarded as technical equipment and technology, and also it was funded by government, thus the cost was not so sensitive. It shows the beginning stage of the green idea, and it mainly focus on the level of the individual building, other than at the city level, so that the greenness is limited to a certain extent. A system thinking of GREEN ideas should integrate different levels of the built environment to have a synergy effect.

\subsection{Mass housing project: Landsea Housing Project, Nanjing}

\subsubsection{Introduction}

With the boom of real estate in China, the idea of Green Building has been inevitably commercialized and has been introduced in mass housing projects, 
among which is the Landsea Project in Nanjing. Landsea is the developer's English name translated from the pronunciation of its Chinese name.

Generally, the climate is rather tough in Nanjing. The city lies in the Coldwinter and Hot-summer region, where the average temperature in January ranges from $-0.4-5.9^{\circ} \mathrm{C}$ and the average temperature in July rises up to $25.9-31.4^{\circ} \mathrm{C}$. The humidity is also very high throughout the year, with $76 \%$ in January and $80 \%$ in July [11]. This high humidity makes the feeling of coldness and hotness much more severe in Nanjing. However, due to the low standard of national thermal design code, there is no infrastructure of district heating or cooling in the city or in rural areas.

The average standard of indoor climate in residential buildings in Nanjing is just beyond the level of health, and much lower than that of comfort, especially during extreme weather. Since the early 1990s, individual air-conditioners have become more and more popular in households in Nanjing due to the increasing family income accompanied with higher demand for indoor comfort. In 2007, each household averaged 1.87 units of air-conditioners in Nanjing [12]. This popularity has even resulted in the new design code for apartments' providing additional exterior air-conditioner decks. The popularity of air-conditioners has caused a lot of problems, such as electricity shortage during summer and winter, though the thermal comfort is not good enough due to air-conditioner's low performance during extreme weather.

\subsubsection{Landsea project}

Generally, the Landsea Project is a typical gated residential project of China. It is located in the new district of Nanjing. A metro line has connected this new district with the main city since 2005 and one of stations is about $500 \mathrm{~m}$ from the Landsea Housing site. The following are some parameters of the project (data from the developer):

- total land area: 13.04 ha for residential and 2 ha for commercial;

- total floor area: $300000 \mathrm{~m}^{2}$ upper ground floor area including residential and commercial, and $80100 \mathrm{~m}^{2}$ underground floor area for car parking and bicycle parking;
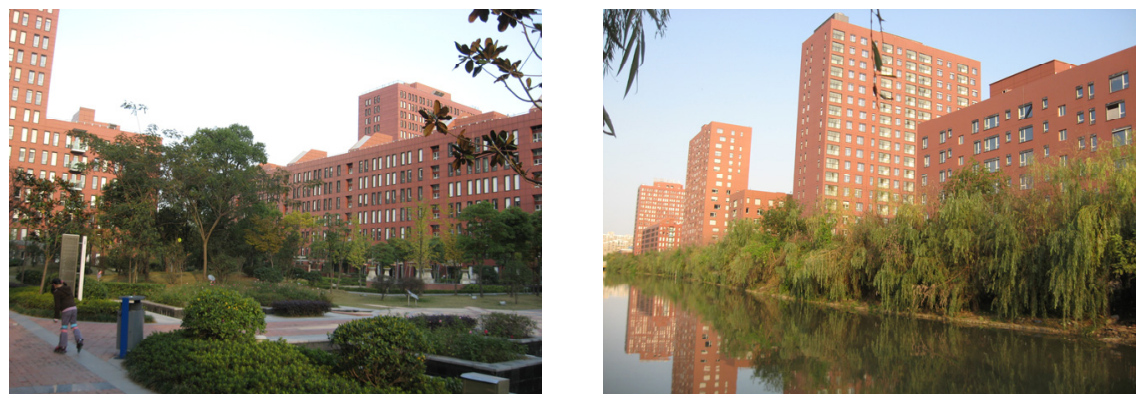

Figure 4: Landsea project, photos taken by the author. 
- status: phase 1 and 2 have been built and sold out, while phase 3 is under construction but also almost sold out;

- price: from RMB8500yuan (2004) to 14500yuan (2008)/ $\mathrm{m}^{2}$ of building area, which includes shared common area), $1 \mathrm{USD}=6.82$ yuan $\mathrm{RMB}$ (rate on Dec 10, 2008 by the Bank of China)

From the technical perspective, the project provides a combination of surface geothermal heat pumps, ceiling heating and cooling, independent mechanical ventilation and a good building envelope.

Table 1: $\quad$ Comparison of $\mathrm{K}$ values.

\begin{tabular}{|l|l|l|}
\hline & Exterior wall $\left(\mathrm{W} / \mathrm{m}^{2} \mathrm{~K}\right)$ & Window $\left(\mathrm{W} / \mathrm{m}^{2} \mathrm{~K}\right)$ \\
\hline Landsea Project & 0.3 & 2.0 \\
\hline $\begin{array}{l}\text { Building code, } \\
(J C J 134-2001)\end{array}$ & $<1.5$ & $2.5-4.7$ \\
\hline $\begin{array}{l}\text { Apartments before } \\
2000\end{array}$ & $\begin{array}{l}>2.0 \\
\text { (plastered 24cm bricks, } \\
\text { without extra insulation) }\end{array}$ & $\begin{array}{l}6.0-6.5 \\
\text { (single glazing with } \\
\text { metal frame) }\end{array}$ \\
\hline
\end{tabular}

The objective of the indoor climate is to keep the temperature at $26^{\circ} \mathrm{C}$ in summer and $22^{\circ} \mathrm{C}$ in winter, with sufficient fresh-air ventilation. Compared to the normal apartments in Nanjing, the indoor thermal comfort is perfect, particularly in winter.

The running fee charged for inhabitants is 21 yuan $/ \mathrm{m}^{2}$.year. The cost of the apartment has risen by $400 y u a n / \mathrm{m}^{2}$ and the apartment's selling price has risen by $3000-4000 y u a n / \mathrm{m}^{2}$. The project's pivotal marketing strategy is the indoor thermal comfort and the promotion of a high standard of living. It has fabricated a gesture of high social class products by the high indoor comfort compared to normal residential buildings.

\subsubsection{Discussions}

As a real estate project, Landsea Housing directly responds to China's specific situation, such as high density, improving life quality, local climate etc. The interior thermal comfort has been greatly improved compared to other normal apartments in Nanjing, though it is merely the same or even lower than that in developed countries. When indoor comfort is discussed in terms of a developing country's situation, the different life standard is considerable and must be taken into account.

Because Landsea Housing is a market-oriented project, measurable indicators and a performance-based evaluation is essential to the economic success, which has been shown by the apartments selling well. The technology implemented in the project is normal technology, other than the fascinating high-tech equipment, which sometimes is very delusive. 
Generally, Landsea Housing is a commercial project and it is also a market oriented one. From the cost-benefit analysis, Landsea is an affordable practice, improving thermal comfort a lot for a limited cost. Surface geo-thermal energy is utilized by heat pumps for both heating and cooling. It could be regarded as "Green Building" practice in this aspect.

However, the project has been over exploited by the developer: Although there is only $400 y u a n / \mathrm{m}^{2}$ more in cost, they charge $4000 / \mathrm{m}^{2}$ more in price, which is only accepted by high-level consumers. Due to their marketing advertising, the project has delivered to the public an image of green buildings as very expensive buildings. This misunderstanding has a bad influence on the acceptance of green practice in the long term.

\section{Discussion and conclusion}

The proportion of energy consumption by the building sector in China is relatively low compared to that in developed countries, and the energy consumption per capita is much lower. This is partly because of low indoor thermal quality. It is however obvious that with economic growth, Chinese households can afford more energy consumption to get greater indoor thermal comfort.

The renovation of traditional buildings could not only improve inhabitants' living conditions at a low cost, but could also promote historical culture and native wisdom. It is of great importance for developing countries. The old wisdom embedded in vernacular architecture shows the importance of adaptation to local climate and geographic conditions in order to acquire a good built environment efficiently. For example, the river in water-town can be used both for transportation and as a cooling source in summer and the heavy earth in cave houses as a good insulator. What should be done further is to establish how the old wisdom could be implemented in a more compact urban situation to respond to the specific challenges resulting from the huge scale urbanization in China.

Both the Eco-office and Landsea Housing are located in an urban context, but they are initiated by different objectives. Government funding and subsidy are very important at the initial development stage of Green Building, but this could result in the negligence of the cost-benefit effect during the green practice.

On the contrary, Landsea Housing responded to the practical situation from the beginning, taking green practice as a marketing lever, thus in the end, had controversial effects on the development of Green Building. Furthermore, the inhabitants in the Landsea Project are very passive and not participating in the process at all. If a platform for the interaction between government, company and inhabitants could be set up, the synergy effect could function as a catalyst for the Green Building development.

To sum up, China, as a large developing country, has a lot of variety in geographic types, climate patterns, vernacular buildings and different living styles. Green Building is essential for China's sustainability strategy and it could have many diversities. An adaptive and holistic approach should be found for the development of Green Building in China. 


\section{Acknowledgements}

Thanks are due to Zhang Hongru, who is the chief architect of the SIBS Ecooffice, and Guo Yonghai, who is the chief manager of the technical centre at the Landsea Company, for their kind and warm support in the two relevant cases studies.

\section{References}

[1] Wang, Dayong, Several acute issues in China's urban planning. Foreign Urban Planning, 20(1), pp. 29-31, 2005. (In Chinese)

[2] National Bureau of Statistics of China, Statistical Yearbook of China, 2007. China Statistics Press, 2007. (In Chinese and English)

[3] Ministry of Land Resources, Report of National Investigation on Land-use Change, 2005 (In Chinese)

[4] World Resources Institute, World Resources Report 2008, World Resources Institute.

[5] G. Assefa, M. Glaumann, T. Malmqvist, B. Kindembe, M. Hult. Environmental assessment of building properties - where natural and social sciences meet: the case of EcoEffect. Building and Environment, 2007(42), pp. 1458-1464, (2007).

[6] Tu Fengxiang, Wang Qinyi, the current status and development of building energy efficiency in China. New Building Materials, 2004(7), pp. 40-42, 2004. (In Chinese)

[7] Centre of Energy Efficiency in Buildings, Minster of Construction of China, Outlook of Designing Standard of Energy Efficiency Building, 2007. (In Chinese)

[8] Ministry of Construction of China, etc. GB 50189-2005, Design Standard of Energy-efficient Public Buildings, China Architecture and Building Press, 2005. (In Chinese)

[9] Duan Tiehu, Li Yanhong, Design of Green Cave Housing, Architectural Journal. 2004(10), 2004. (In Chinese)

[10] Shanghai Institute of Building Science, Simulation and analysis of energy efficiency of Shanghai eco-office. 2005. (In Chinese)

[11] ASHRAE, Climate Design Data 2005 ASHRAE Handbook, 2005

[12] Nanjing Bureau of Statistics, Statistical yearbook of Nanjing, 2007, 2008. (In Chinese) 